\title{
GREEN ECONOMY AS A NEW OPPORTUNITY TO STIMULATE EXPORT AND ATTRACT INVESTMENTS, THE CASE OF GEORGIA
}

\author{
Vazha Verulidze ${ }^{1}$, Astrida Miceikiene $\dot{e}^{2}$ \\ ${ }^{1}$ Prof. Batumi Shota Rustaveli State University, Georgia, E-mail address: vazha.verulidze@bsu.edu.ge \\ ${ }^{2}$ Prof. dr. Vytautas Magnus University, Lithuania, E-mail address: astrida.miceikiene@vdu.lt
}

Received 0909 2021; Accepted 13102021

\begin{abstract}
Green economy (European Green deal) is one of the main strategies implemented by the European Union (EU). Authors analyzing the trends of green economy in EU. Green economy Lithuania is one of the most important topics of research too. Green Economy in Europe will encourage the creation and development of environmentally friendly business, innovation, production, and health care. It will be an economic phase of a whole new quality that will require a new generation of leadership skills, while also having the potential to be the beginning of a new society and a new perception of welfare. The importance and relevance of the topic lies in identifying the reasons that led to the stagnation of the agricultural sector and demonstrating new opportunities that will create possibilities for sustainable development in the context of organic agriculture. The article also attempts to compare the current situation in agriculture in Georgia and Lithuania in terms of bioeconomic development and growth in the export potential of bioproducts. In the article used the research methods like scientific abstraction, comparison of information, generalization, analysis, and synthesis were also used. The empirical basis of the research is the official information of the National Statistics Office of Georgia, the normative acts of the Government of Georgia and scientific publications. These methods enabled us to study the economic events and their interaction. The article concludes that one of the alternative directions for the growth of the agrarian economy is to promote the development of the bioeconomy in Georgia, for which it is advisable to accelerate the development of agricultural infrastructure, privatize state lands with the condition of developing biological farms and prepare a regulatory framework that will stimulate the production and export of biological products.
\end{abstract}

Keywords: Bioeconomy, organic production, subsistence agriculture.

JEL Codes: Q51, Q56.

\section{Introduction}

Analysis of the situation in Georgia's agriculture confirms that the traditional agricultural sector cannot develop and compete in external or internal markets, therefore, the agricultural economy does not grow, and in the absence of a defined market matching the growth, there is insufficient incentive for investment. The country fails not meet the needs of the population for food, despite the fact that the area of agricultural land is more than 3 million hectares and occupies $43.3 \%$ of the total area of the country. The share of state land in the total area of agricultural land is large. Only $25 \%$ of agricultural land has been privatized. $80 \%$ of the population employed in agriculture is self-employed, indicating a high proportion of subsistence agriculture. From
2013 to 2020, the production of crop and livestock products has been declining over time, the acreage for autumn and spring crops has also decreased over the same period. In the same period, in Lithuania, both exports and imports of food and beverages slightly decreased over time, but investments increased significantly, as did the production of crops and acreage, unlike the production of livestock products, which did not increase. 95\% of agricultural land is privately owned, while organic farms account for $8 \%$ of the total area, close to the European average.

The main challenge for the agricultural sector in Georgia is the country's food selfprovisioning, the development of export production and settling on the international

Copyright (C) 2021 Author(s), published by Vytautas Magnus University. This is an open access article distributed under the terms of the Creative Commons Attribution Non-Commercial 4.0 (CC BY-NC 4.0) license, which permits unrestricted use, distribution, and reproduction in any medium provided the original author and source are credited. The material cannot be used for commercial purposes 
market, however, with the current agrarian policy, the country failed to address this challenge, and also failed to analyze and evaluate the emergence of new opportunities in the context of supporting a green economy, as evidenced by the formal nature of the document adopted by the Georgian government on July 30, 2013 Ordinance on Bioproduction, since no real measures have been taken since then, and the share of bioproducts in Georgia's agriculture does not exceed $1 \%$. Georgia has natural and climatic conditions for the production of organic agricultural products, thus, agriculture is a very sector, where the capacity for the development of a green economy lies, and where, under the effective management of still unused resources, it is possible to reduce imports of agricultural products and stimulate exports. This provides a new chance for the progress of the agricultural sector and changing the reality in which the agricultural sector has found itself.

The purpose of this article is to assess the causes of stagnation in agriculture in Georgia and substantiate the possibility of sustainable agricultural development in the context of providing incentives for the development of biofarms and stimulating the bioeconomy from the state, achievable by exporting organic agricultural products in condition a healthy investment climate. The article also aims to highlight the importance of stimulating the growth of organic farms and the export of organic products in Lithuania (Savickiene, Miceikiene, 2017).

\section{Research results}

The modern world is fundamentally changing attitudes towards the negative impact of economic growth on the environment. EU4Environment is helping Georgia facilitate national policy dialogues on green economy, because In 2014, Georgia and the European Union signed an Association Agreement that came into force in 2016. It encompasses objectives related to sustainable development and environment. (Eu4Environment. 2021). In 2017-2018, the United Nations Environment Programme and the Georgian Ministry of
Economy and Sustainable Development collaborated on the preparation of a study that would inform the National Green Economy Strategy as part of the Greening Economies in the European Union's Eastern Neighborhood.

Georgia's Green Economy Strategy includes infrastructure investments in agriculture, buildings and the tourism sector. The formation of the green economy sector towards agriculture is due to the presence of significant potential for the development of the bioeconomy in the country. Bioeconomy is becoming the main driver transforming European agri-food value chains towards global sustainability in the food supply chain. (Francisco, et al., 2021). It is estimated that Research, De-velopment and Innovation associated with the Bio-economy strategy under the EU Horizon 2020 programme can generate about 130,000 jobs and 45 billion $€$ in added value in Bioeconomy sectors by 2025 (Electra, et al., 2018). The bioeconomy is a fundamental pillar of the Italian economy and an enabling element of the Italian new green deal. (Fabio, et al., 2021).

Year by year, interest in the organic market is increasing all over the world. According to STATISTA, worldwide sales of organic food quintupled in the 21 st century (18 billion USD in 2000, versus 90 billion USD in 2016), while, according to TechSci Research, the total worth of the market is projected to grow at a compound annual growth rate (CAGR) of $16.15 \%$ during the period 20172022. In fact, in some developed countries, the growth of supply of organic foods cannot keep up with the growth of demand (OCA, 2018), as the transition from conventional to organic farming is a prolonged process. (The Financial. 2018).

The process of transformation of the agricultural sector in Europe and other countries, fueled by the development of the bioeconomy, through the support of the green economy, has opened up new opportunities for Georgia to ensure an inflow of investments in this sector, sustainable economic development and export growth, which has remained an insurmountable challenge so far.

Georgia, being a developing country with a weak economy, which consumes much 
more than it produces, should look for alternative ways of economic growth. The traditional agricultural sector is unable to develop and withstand competition either on the external or internal market, and the country has a chronically negative foreign trade balance. On average, $70 \%$ of foreign trade turnover is accounted for by imports. (External Trade. 2020). About $\$ 1$ billion worth of food and beverages are imported annually. (Figure 1) (Import. 2020). Given the resource potential of the country, the share of agricultural products in the largest export commodity positions is very small and is limited only to: natural grape wines, mineral and fresh waters, spirits and nuts. Wheat has a dominant import position. (External Trade..., 2019). The country is unable to meet the needs of its population for food, despite the fact that the area of agricultural land is more than 3 million hectares and occupies $43.3 \%$ of the total area of the country (which is 30.3 thousand $\mathrm{km}^{2}$ ), (Rural Development..., 2021). Against this background, the country's economic security is also fragile.

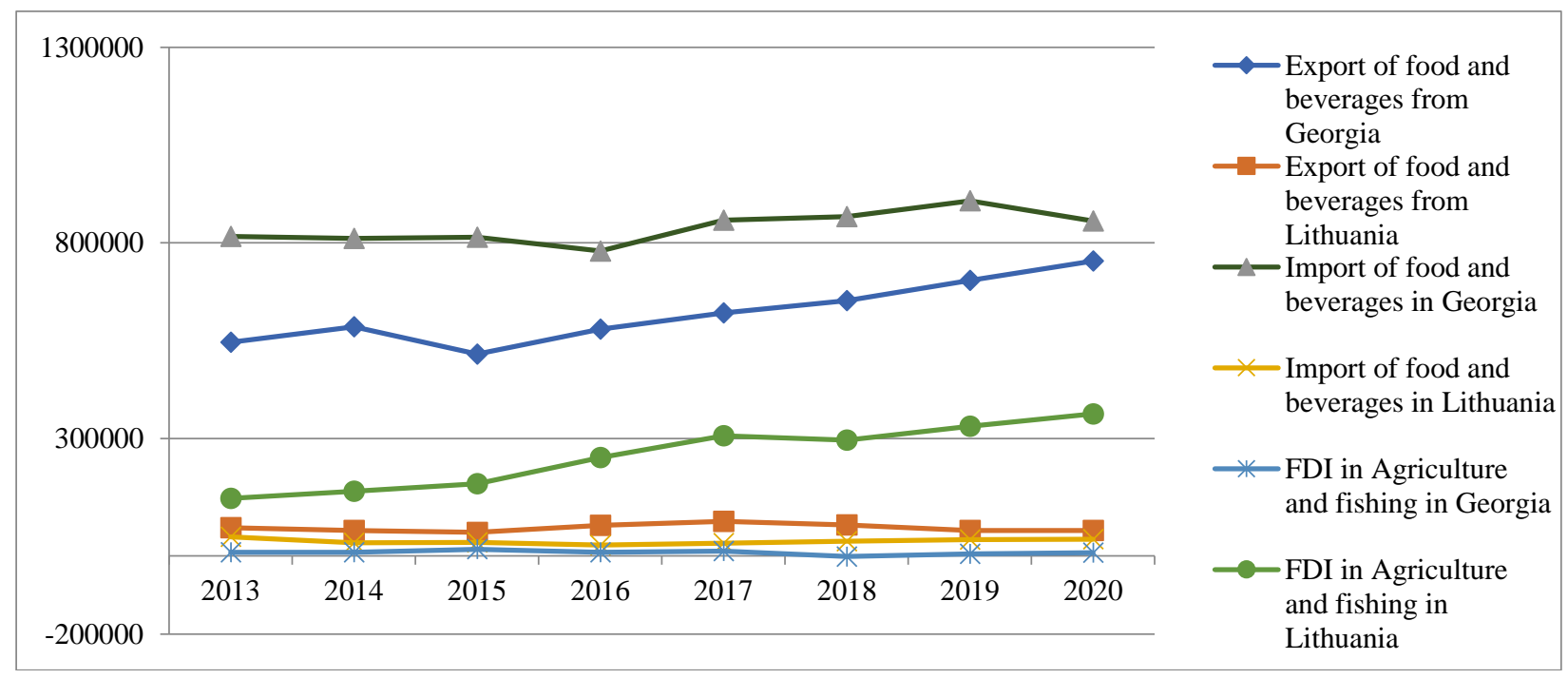

Figure 1. Agricultural development indicators in Georgia and Lithuania, in Thousands of Euros

Most of the agricultural land in Georgia is not developed, which hinders the modernization of agriculture and the development of the land market. According to the 2014 agricultural census conducted in accordance with the World Program for the Census of Agriculture, recommended by the Food and Agriculture Organization (FAO), as of October 1, 2014, 681.1 thousand hectares of agricultural land were used by households, and 106.6 thousand hectares of agricultural land by legal entities (Census of Agriculture.
2014). The share of households in crop and livestock production is very high, namely, the share of wheat in 2019 is $85 \%$, vegetables $91 \%$, cucurbits crops - 100\%, fruits - $97 \%$, citrus fruits $-99 \%$ and grapes $-86 \%$. The share of households in production, especially milk and meat, is also high (Statistical Yearbook..., 2020). 


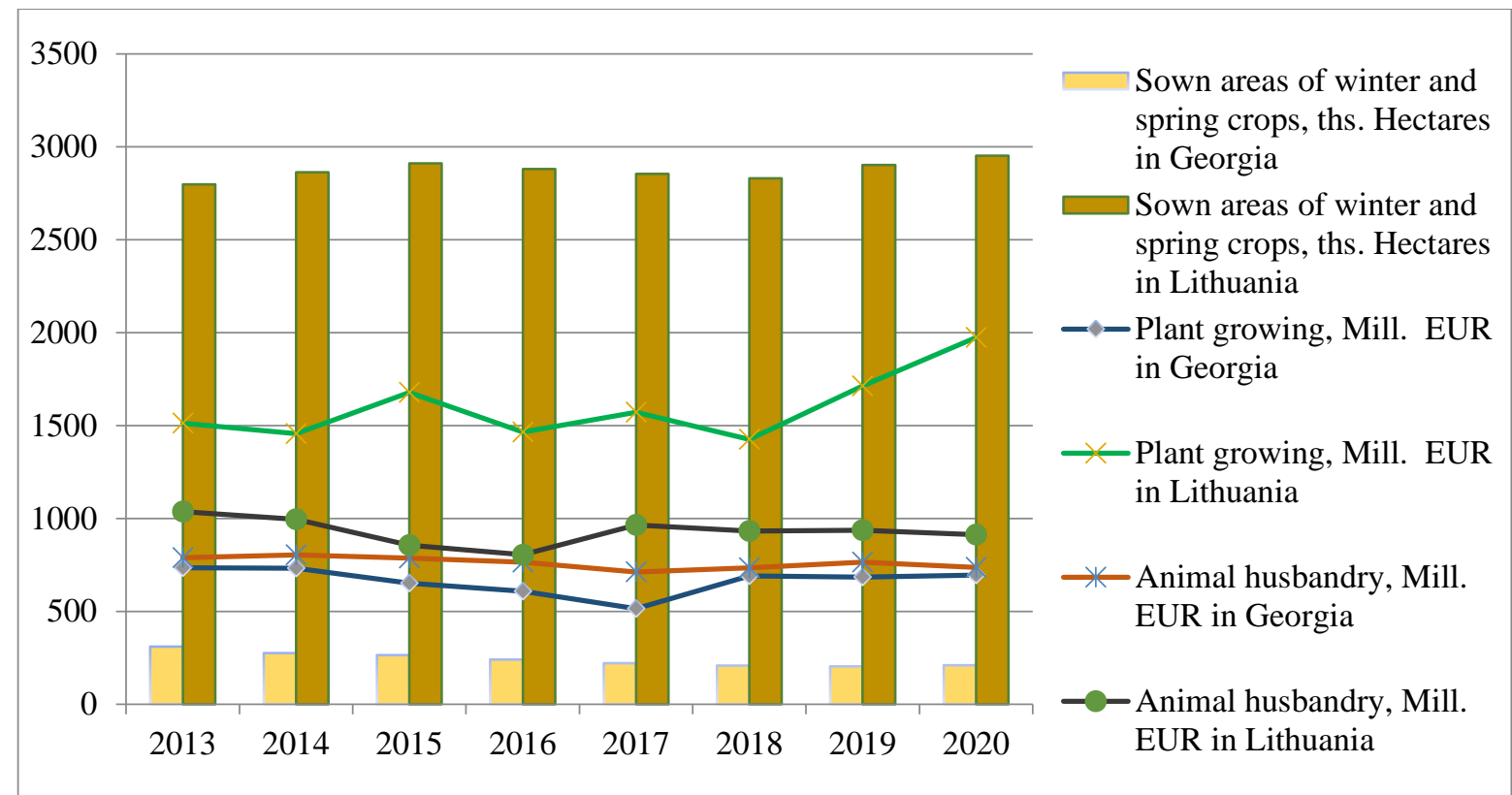

Figure 2. Production of crop and livestock products in Georgia and Lithuania

From 2013 to 2020, the production of crop and livestock products has been declining over time, the acreage for autumn and spring crops has also decreased over the same period (Figure 2). According to the National Statistical Office, the area occupied by perennial plantations is 120.8 thousand hectares, which has not changed since 2017.

The share of state land in the total area of agricultural land is large. According to the FAO study, only $25 \%$ of agricultural land has been privatized, and only $55 \%$ of 801.8 thousand hectares of arable land have been privatized, the remaining 363.3 thousand hectares are still owned by the state, and the state sells them through public Internet auctions (The European...,2012). In Lithuania $95 \%$ of agricultural land is privately owned, while organic farms account for $8 \%$ of the total area, which is close to the European average. (Organic farming...,2021). During the analyzed period in Lithuania, both exports and imports of food and beverages slightly decreased over time, but investments increased significantly (Figure 1). Crop production and acreage are also increased, but livestock production did not. (Figure 2).

Since 2012, agriculture was declared one of the priorities of economic development in Georgia and the implementation of measures and projects started, aimed at facilitating the development of the sector. Important steps were taken to revive practically destroyed the agricultural sector and for this solid financial resources were spent from the state budget (Verulidze. 2020).

In Georgia, measures taken by the state in the context of undeveloped (especially irrigation and drainage systems) infrastructure failed to stimulate the agricultural sector. Analysis of the current situation in Georgia's agriculture confirms that the agricultural economy is not growing in dynamics, and since growth is unpromising, in the absence of matching sales market, there is no sufficient motivation for investment. Correlation analysis shows that there is no feedback between investments made in the analyzed period, exports and output of crop production (correlation coefficient is negative), there is no correlation between investments and livestock production (correlation coefficient is 0.28 ). On the other hand, there is a weak correlation between the area under autumn and spring crops and investments (correlation coefficient is 0.47), which indicates that investments are mainly associated with the purchase and use of agricultural land for non-agricultural purposes.

An alternative way to improve the situation in Georgia's agriculture is to promote a green economy, where with effective management of still unused resources, it is possible to reduce imports of agricultural products and stimulate exports, which gives a 
new chance for progress in the agricultural sector and changes the reality in which Georgia has found itself. With the development of a green economy, the country can become a producer and supplier of bioproducts for both the EU and other countries. The green economy could become one of the main sectors of the economy instead of the tourism sector, which is very fragile and unreliable during the crisis.

Georgia's green growth ambitions aim to curb its annual carbon dioxide emissions and increase the number of green jobs in the long run. Regarding jobs, the emphasis is on the development of the agriculture sector. It is the most important contributor to employment in Georgia, providing employment to approximately $45 \%$ of the total workforce (World Bank, 2019). Around $80 \%$ of the workforce employed in agriculture is selfemployed, which indicates a high share of subsistence agriculture (Green Economy..., 2019) In Lithuania only $55 \%$ are selfempoyed.

The main challenge for the agricultural sector in Georgia is the country's food selfprovisioning, the development of export production and settling on the international market, however, with the current agrarian policy, the country failed to address this challenge, and also failed to analyze and evaluate the emergence of new opportunities in the context of supporting a green economy, as evidenced by the formal nature of the document adopted by the Georgian government on July 30, 2013 Ordinance on Bioproduction (Organic production. 2013). since no real measures have been taken since then, and the share of bioproducts in Georgia's agriculture does not exceed $1 \%$. (Share of..., 2021). Currently, there are only a few certified companies in Georgia that produce organic products, including bio wine (at this stage, the list of entrepreneurs in Georgia includes up to 35 organic viticulture/wine-making, up to 10 in transitional stages and up to 25 uncertified) (Lack of..., 2021), organic essential oils, organic cereals and fruits, organic nuts, organic tea, organic berries. They also collect and sell wild plant products, (Agrarian Movement..., 2020).

In December 2017, non-entrepreneurial (non-commercial) legal entity founded in Georgia, the Association of Georgian Organic Agricultural Producers of Georgia, was created with an enthusiastic idea, which implies: Promotion of organic production methods throughout the country; Reducing the harmful effects of conventional agriculture on humanand environmental health (Association of..., 2021).

Since 1999 Company "Georgia's Natural" Produces several denominations of products and has been working persistently to diversify the international markets enabling annual sustainable growth of export (Georgia`s Natural. 2021).

By the Agrarian Movement of Georgia has been prepared "Market potential and feasibility study for organic agricukture" for the "GRETA" project - Green Economy: Sustainable Mountain Tourism and Organic Agriculture. The goal of this research was the identification of the most suitable products (value chains) for organic production. (Market Potential". 2018). The project was funded and covers three regions of Georgia: Upper Svaneti, Racha and Upper Imereti; Its total cost is 6.8 million Euros and is funded by the governments of the EU and two EU member states, Austria and Sweden. (Green Economy..., 2018).

Lithuania has the biggest in Europe organic company Auga group. Last year (August-December), over 144 thousand tons of organic raw materials (grain, legumes and rapeseed) were purchased and exported from Lithuanian organic farms. Most of it was organic wheat - 76,474 tons and oats - 21,444 tons.

In Lithuania, 2731 certified farms are engaged in organic farming, their cultivated areas reach 246 thousand. hectares, of which 150 thousand. hectares are arable land and the rest are meadows.

Compared to Georgia, Lithuania has much better starting conditions for the development of the bioeconomy and the 
growth of exports of bioproducts. In a view of the decline in exports during the analyzed period, it is especially important for Lithuania to take additional measures to stimulate the growth of organic farms and the export of organic products.

\section{Conclusion}

Based on the results of the study, the following conclusion can be drawn:

Most of the agricultural land in Georgia is undeveloped, the share of households in crop and livestock production is high, only $25 \%$ of agricultural land and $55 \%$ of arable land have been privatized. About $80 \%$ of the rural labor force is self-employed, which indicates the existence of subsistence farming, cooperative farms cannot develop and, as a result, agriculture does not grow adequately. The mismatch between the demand and supply of agricultural products produced in Georgia hinders sales both on the domestic and foreign markets.
The situation is much better in Lithuania, where $95 \%$ of agricultural land is privately owned and $55 \%$ of the workforce is selfemployed, although food exports are not increasing. Lithuania has the potential to increase the export of bioproducts.

At this stage, there is a resource potential for the growth of the agrarian economy of Georgia in the direction of bioeconomy, for the development of which it is advisable to accelerate:

1. Agricultural infrastructure development process;

2. Privatization of state land with the condition of the development of biofarms, which will also contribute to the development of the land market;

3. Preparation of a regulatory framework that will stimulate the production and export of bioproducts.

4. Promotion of production and export of organic products, support for such producers.

5. Promotion of agricultural cooperation.

\section{References}

Agrarian Movement of Georgia. 2020. Organic farming in Georgia. Available at http://www.agropedia.ge/news/735 (accessed on 24/03/2021)

Association of Georgian Organic Agricultural Producers of Georgia. 2021. Available at http://www.organicgeo.ge/en/about-us/ (accessed on 07/04/2021)

Census of Agriculture . 2014. Available at https://www.geostat.ge/media/22760/AG-CensusRelease_ENG_2016.pdf (accessed on 18/02/2021)

Electra, P., Konstantinos, V., Ioannis, F., Giorgos, T., Konstantinos, C., Dimitrios, B., Constantina, K., Konstantinos, E. 2018. Bio-economy in Greece: Current trends and the road ahead. The EuroBiotech Journal. Volume 2, Issue 3, pp. 137-145. https://doi.org/10.2478/ebtj-2018-0018

Eu4Environment. 2021. Georgia. Available at https://www.eu4environment.org/where-we-work/georgia/ (accessed on 04/05/2021)

External Trade of Georgia. 2019. Available at https://www.geostat.ge/media/32462/External-Merchandise-Trade2019_publication-2020.pdf (accessed on 06/07/2021)

External Trade. 2020. National Statistics of Georgia. Available at https://www.geostat.ge/en/modules/categories/35/external-trade (accessed on 03/05/2021)

Fabio, F., Lucia, G., Patrizia, B., Piergiuseppe, M., Daniela, A., Andrea, L. 2021. The bioeconomy in Italy and the new national strategy for a more competitive and sustainable country. New Biotechnology. Volume 61, pp. 124-136. https://doi.org/10.1016/j.nbt.2020.11.009

Francisco, J., María, D., Pascual, O., Antonio, J., Richard, G. 2021. Bioeconomy as a transforming driver of intensive greenhouse horticulture in SE Spain. New Biotechnology. Volume 61, pp. 50-56. https://doi.org/10.1016/j.nbt.2020.11.010

Georgia`s Natural. 2021. Corporate Info. Available at https://georgiasnatural.com/en/about-us/corporate-info (accessed on 03/05/2021)

Green Economy Analysis in Georgia: A Sustainable Asset Valuation for the analysis of sustainable infrastructure investments. (2019). Available at https://www.iisd.org/system/files/2020-09/savi-green-economy-georgia.pdf (accessed on $15 / 08 / 2021)$

Green Economy: Sustainable Mountain Tourism and Organic Agriculture. GRETA. 2018. Available at https://drive.google.com/file/d/1vjVnkbmPYjjTZJmHMQyljr46qO5svDra/view (accessed on 08/05/2021) 
Import. 2020. National Statistics of Georgia. Available at https://www.geostat.ge/en/modules/categories/638/import (accessed on 07/04/2021)

Lack of organic products on the market. Business partner. 2021. Available at https://business-partner.ge/soflismeurneoba/bioproduktebis-defitsiti-bazarze-da-stimuli-metsarmeebistvis (accessed on 08/07/2021)

Market Potential And Feasibility Study For Organic Agriculture. GRETA. 2018. Available at https://drive.google.com/file/d/1jGIHyoJBig91mOBeQzaRRTari3bPzBoe/view (accessed on 08/05/2021)

Organic farming statistics. Eurostat. 2021. Available at https://ec.europa.eu/eurostat/statisticsexplained/index.php?title=Organic_farming_statistics (accessed on 01/09/2021)

Organic production. Ordinance of the Government of Georgia. 2013. Available at https://matsne.gov.ge/ka/document/view/1978999?publication=0 (accessed on 09/08/2021)

Rural Development Strategy of Georgia. (2021-2027). Available at https://mepa.gov.ge/Ge/PublicInformation/20395/ (accessed on 11/03/2021)

Savickienè, Jūratė; Miceikienè, Astrida; Lalić, Srdjan. 2017. Trend of sustainable economic development of family farms: case of Lithuania // Management theory and studies for rural business and infrastructure development = Vadybos mokslas ir studijos - kaimo verslų ir jų infrastruktūros plètrai [elektroninis išteklius]: mokslo žurnalas / Aleksandro Stulginskio universitetas, Lietuvos agrarinès ekonomikos institutas. Akademija. ISSN 2345-0355, T. 39, nr. 4 (2017), p.465-489.

Share of organic products in Georgian production. Commersant. 2021. Available at https://commersant.ge/ge/post/qartul-warmoebashi-bio-produqtebis-wili-1-s-ar-agemateba (accessed on 30/08/2021)

Statistical Yearbook of Georgia. 2020. Available at https://www.geostat.ge/media/35684/Yearbook_2020.pdf (accessed on 07/05/2021)

The European Union's Neighbourhood Programme. 2012. Assessment of the Agriculture and Rural Development Sectors in the Eastern Partnership countries Georgia. p. 11. Available at http://www.fao.org/3/aq673e/aq673e.pdf (accessed on 26/02/2021)

The Financial. 2018. Organic is the new black!. Available at https://www.finchannel.com/opinion/analysis3/71737-organic-is-the-new-black (accessed on 03/05/2021)

Verulidze, V. 2020. TRENDS IN THE DEVELOPMENT OF AGRICULTURE IN CONDITIONS OF TAX REFORM IN GEORGIA. Proceedings of the 2020 International Scientific Conference "Economic Science for Rural Development". Issue 53. Jelgava, LLU ESAF. pp. 252-259 